\title{
IDENTIFIKASI CEMARAN LOGAM BERAT PADA TEMPE DI PENGRAJIN TEMPE X DAN Y KOTA BENGKULU
}

\author{
Eldania Risalatuzain, Betty Yosephin, Yenni Okfrianti \\ Politeknik Kesehatan Kementerian Kesehatan Bengkulu, Jurusan Gizi \\ risalatuzain@gmail.com
}

\begin{abstract}
Tempe fermentation process, hygiene is very influential on the resulting product. Industry tempe Indonesia which has applied hygiene principles about 5\%. Contamination of heavy metals food need to be awere that the realization of assurance and food safety. Metal can cause poisoning (toxicity) and this very danger for living beings (animalsand humans), such metals include lead $(\mathrm{Pb})$, mercury ( $\mathrm{Hg}$ ), arsenic (As), and cadmium (Cd). The purpose of this study is to determine contamination of heavy metals in tempe in craftsmen tempe $\mathrm{X}$ and $\mathrm{Y}$ of the city of Bengkulu. Design this research is descriptive a qualitative observational approach using laboratory test in tempeh craftsmen tempe $\mathrm{X}$ and $\mathrm{Y}$ of the City of Bengkulu. There area test conducted in the laboratory, namely cadmium (Cd), lead $(\mathrm{Pb})$, tin $(\mathrm{Sn})$, and mercury $(\mathrm{Hg})$. Result of this study showed that the maximun limit of the terms of the according to the BSN 2015. The conclusion of this reserch is that the heavy metal content of lead, cadmium, mercury on tempe $\mathrm{X}$ and $\mathrm{Y}$ craftsmen in Bengkulu City within safe limits of tempe quality requirements according to BSN 2015.This research suggestions can identify tempe content from other tempe quality requirements.
\end{abstract}

\section{Keywords : Tempe, Quality Requirements Tempeh, Heavy Metals}

\begin{abstract}
Abstrak:Proses fermentasi tempe, higiene memegang peran penting untuk menghasilkan produk yang sehat. Industri tempe Indonesia yang telah menerapkan prinsip higienesekitar 5\%. Cemaran logam berat pada makanan perlu diketahui agar terwujudnya keterjaminan dan keamanan makanan. Logam dapat menyebabkan keracunan (toksisitas) dan ini sangat berbahaya bagi makhluk hidup (hewan dan manusia), logam tersebut meliputi timbal $(\mathrm{Pb})$, merkuri $(\mathrm{Hg})$, Arsen (As), dan kadmium (Cd). Tujuan penelitian ini untuk mengetahui cemaran logam berat pada tempe di pengrajin tempe X dan Y Kota Bengkulu. Desain penelitian ini adalah deskriptif kualitatif dengan pendekatan observasional menggunakan pemeriksaan laboratorium pada tempe di pengrajin tempe X dan Y Kota Bengkulu. Penelitian yang dilakukan terdapat 4 uji di laboratorium yaitu kadmium (Cd), timbal, $(\mathrm{Pb})$, timah $(\mathrm{Sn})$, dan merkuri $(\mathrm{Hg})$. Hasil penelitian ini menunjukan bahwa terdapat kandungan logam berat pada tempe di pengrajin $\mathrm{X}$ dan $\mathrm{Y}$ tetapi masih dibawah batas maksimum dari syarat mutu tempe menurut BSN 2015. Kesimpulan penelitian ini bahwa kandungan logam berat timbal, cadmium, timah, dan merkuri pada pengrajin tempe X dan Y Kota Bengkulu dalam batas aman dari syarat mutu tempe menurut BSN 2015. Saran penelitian ini dapat mengidentifikasi kandungan tempe dari syarat mutu tempe lainnya.
\end{abstract}

Kata Kunci: Tempe, Syarat Mutu Tempe, Logam Berat

Kedelai merupakan sebagai sumber hari dan sudah populer dikalangan antioksidan isoflavon. Kedelai juga masyarakat. Sudah ada berbagai produk mudah diperoleh dalam makanan sehari- olahan dari kedelai yang sudah banyak 
010 Jurnal Media Kesehatan, Volume 11 Nomor 2, Desember 2018, hlm. 009-016

dimanfaatkan masyarakat untuk kedelai dan dilanjutkan dengan proses memenuhi kebutuhan zat gizi dalam fermentasi. Proses pembuatan tempe yaitu bahan makanan (Astuti, S., 2008). meliputi dari pencucian kedelai, Beberapa produk olahan berbahan dasar perebusan, perendaman, pengupasan kulit kedelai yaitu tempe, tahu, tauco, kecap, kedelai, inokulasi, pembungkusan hingga tauge dan sebagai bahan campuran fermentasi (Sarwono, 2004). Pada proses makanan ternak (Marliah Ainun, dkk., fermentasi tempe, higiene sangat 2012). berpengaruh terhadap produk yang

Konsumsi kedelai rat-rata per dihasilkan (Mutiara, 2010). kapita per tahun nasional adalah yaitu 8.5 Prinsip-prinsip higiene meliputi proses $\mathrm{kg} / \mathrm{kapita} / \mathrm{tahun}$ (Astawan, 2015). produksi dengan 2 kali pemanasan, Konsumsi protein nabati kacang kedelai di kebersihan dan kesehatan pekerja, serta daerah Kota Bengkulu berdasarkan hasil kebersihan lingkungan dan alat-alat yang laporan Dinas Badan Ketahanan Pangan digunakan selama proses produksi tahun 2016 yaitu 37.8 kkal/kapita/hari (Bintara 2013; Bintara \& Maskar 2012). sedangkan pada tahun 2017 konsumsi Hanya saja industri tempe Indonesia yang protein nabati kacang kedelai di Kota telah menerapkan prinsip higiene sekitar Bengkulu yaitu $45.6 \mathrm{kkal} / \mathrm{kapita} / \mathrm{hari}$ (Ketahanan Pangan Provinsi Bengkulu, 2017).

Tempe merupakan jenis makanan yang mudah rusak dan penyimpanan tempe tidak lama hanya 2-3 hari saja. Tetapi tempe memiliki komposisi zat gizi yang lebih baik. Kandungan komposisi zat gizi tempe dalam 100 gram adalah $20.8 \mathrm{~g}$ protein, $8.8 \mathrm{~g}$ lemak, $13.5 \mathrm{~g}$ karbohidrat, $0.19 \mathrm{mg}$ vitamin B1 dan $155 \mathrm{mg}$ kalsium, tetapi sedikit mengandung serat (Jubaidah, Siti, 2016).

Cara membuat tempe terdiri dari 2 bagian besar, yaitu proses pemasakan kedelai. masuknya suatu kontaminan kedalam makanan. Kontaminan ini merupakan bahan biologi ataupun kimia, bahan asing atau bahan yang tidak sengaja masuk atau ditambahkan ke dalam makanan yang menyebabkan keamanan pangan (Rauf, R., 2013). Kontaminasi silang melalui manusia atau peralatan yang tercemar. Kontaminasi langsung melalui bahan yang digunakan untuk pembuatan tempe, yakni kedelai dan air yang digunakan untuk merebus, merendam maupun mencuci 
Ada beberapa unsur logam mengidentifikasi cemaran logam berat termasuk dalam elemen mikro merupakan yaitu kadmium $(\mathrm{Cd})$, timbal $(\mathrm{Pb})$, timah kelompok dari logam berat yang tidak (Sn), dan merkuri $(\mathrm{Hg})$ pada tempe di memiliki fungsi biologis disampulkan dari pengrajin tempe X dan Y Kota Bengkulu. penelitian tentang kontaminasi logam berat pada makanan serta dampaknya pada kesehatan. Logam berat menyebabkan keracunan (toksisitas) dan ini sangat berbahaya bagi makhluk hidup (hewan dan manusia), logam tersebut meliputi timbal $(\mathrm{Pb})$, merkuri $(\mathrm{Hg})$, arsen (As), dan kadmium (Cd)(Agustina, Titin., 2010).

Menurut Badan Standarisasi Nasional (BSN) (2015) bahwa syarat mutu tempe menurut SNI 3144-2015 yaitu dilihat dari organoleptik (bau, warna, dan rasa), kadar air, kadar abu, kadar lemak, kadar protein, kadar serat kasar, cemaran mikroba (Salmonella negatif/25 g), cemaran arsen dan cemaran logam berat (kadmium, timbal, merkuri, dan timah). Syarat mutu tempe kedelai menurut BSN 2015 dilihat dari cemaran logam seperti kadmium (Cd) maks $0.2 \mathrm{mg} / \mathrm{kg}$, timbal $(\mathrm{Pb})$ maks $0.25 \mathrm{mg} / \mathrm{kg}$, timah (Sn) maks $40 \mathrm{mg} / \mathrm{kg}$, dan merkuri $(\mathrm{Hg}) 0.03 \mathrm{mg} / \mathrm{kg}$. Oleh karena itu pencemaran logam berat pada makanan perlu diketahui agar terwujudnya keterjaminan dan keamanan makanan. Tujuan dari penelitian ini adalah

\section{BAHAN DAN CARA KERJA}

Penelitian ini menggunakan studi deskriptif dengan pendekatan observasional. Sampel dalam penelitian ini adalah tempe dari pengrajin $\mathrm{X}$ dan $\mathrm{Y}$ Kota Bengkulu. Pada sampel tempe $X$ yang dipilih yaitu tempe pengrajin tempe yang telah menerapkan higiene dan sanitasi. Pada sampel tempe $\mathrm{Y}$ yang dipilih yaitu tempat pengrajin tempe yang belum menerapkan higiene dan sanitasi. Penentuan sampel ditentukan dengan menggunakan lembar ceklist penilaian tempat produksi. Pengumpulan data dilakukan dengan mengujikan sampel produks tempe di laboratorium yang terakreditasi oleh Komisi Akreditas Nasional (KAN).

\section{HASIL}

\section{Kandungan Logam Berat Tempe X}

Berdasarkan penelitian dilakukan uji laboratorium empat cemaran logam yaitu Kadmium (Cd), Timbal $(\mathrm{Pb})$, Timah (Sn), dan Merkuri (Hg).

Tabel 1. Cemaran Logam Berat Pada Tempe $X$

\begin{tabular}{llll}
\hline Cemaran Logam & Satuan & Persayaratan SNI & Hasil \\
\hline
\end{tabular}




\begin{tabular}{lccc}
\hline Kadmium $(\mathbf{C d})$ & $\mathrm{mg} / \mathrm{kg}$ & Maks 0.2 & $<0.004$ \\
Timbal $(\mathbf{P b})$ & $\mathrm{mg} / \mathrm{kg}$ & Maks 0.25 & $<0.031$ \\
Timah $($ Sn) & $\mathrm{mg} / \mathrm{kg}$ & Maks 40 & $<0.8$ \\
Merkuri $(\mathbf{H g})$ & $\mathrm{mg} / \mathrm{kg}$ & Maks 0.03 & $<0.005$ \\
\hline
\end{tabular}

Berdasarkan Tabel 1. dapat Kandungan Logam Berat Tempe Y

diketahui bahwa dari 4 uji logam berat pada tempe $\mathrm{X}$ kandungan kadmium, timbal, timah, dan merkuri dibawah batas maksimum atau berada dalam batas normal.
Berdasarkan penelitian dilakukan uji laboratorium empat cemaran logam yaitu Kadmium $(\mathrm{Cd})$, Timbal $(\mathrm{Pb})$, Timah (Sn), dan Merkuri (Hg).

Tabel 2. Cemaran Logam Berat Pada Tempe Y

\begin{tabular}{lccc}
\hline \multicolumn{1}{c}{ Cemaran Logam } & Satuan & Persayaratan SNI & Hasil \\
\hline Kadmium $(\mathbf{C d})$ & $\mathrm{mg} / \mathrm{kg}$ & Maks 0.2 & $<0.004$ \\
Timbal $(\mathbf{P b})$ & $\mathrm{mg} / \mathrm{kg}$ & Maks 0.25 & $<0.031$ \\
Timah $($ Sn) & $\mathrm{mg} / \mathrm{kg}$ & Maks 40 & $<0.8$ \\
Merkuri $(\mathbf{H g})$ & $\mathrm{mg} / \mathrm{kg}$ & Maks 0.03 & $<0.005$ \\
\hline
\end{tabular}

Berdasarkan Tabel 2. dapat BBIA (Balai Besar Industri Agro) Bogor diketahui bahwa dari 4 uji logam berat yang telah terakreditas KAN (Komisi pada tempe Y kandungan kadmium, Akreditas Nasional) untuk melihat timbal, timah, dan merkuri dibawah batas kandungan logam berat yang terdapat maksimum atau berada dalam batas didalam tempe. Adapun beberapa normal.

\section{PEMBAHASAN}

Keamanan pangan sangat penting untuk semua bahan pangan, salah satunya terhindar dari cemaran logam berat pada makanan. Untuk mengetahui kandungan logam suatu produk pangan memenuhi syarat sesuai SNI (Standar Nasional Indonesia) yang ditetapkan atau tidak, perlu dilakukan pengujian (BPOM RI, 2009). Maka dari itu dilakukan pengujian lebih lanjut di laboratorium Badan Penelitian dan Pengembangan Industri pengujian yang dilakukan pada penelitian ini yaitu kadmium (Cd), timbal $(\mathrm{Pb})$. Timah (Sn) dan merkuri (Hg).

Jika kandungan logam berat melebihi syarat SNI dan dikonsumsi oleh tubuh manusia akan menyebabkan meracunan (toksisitas). Penelitian Titin Agustin (2010) menyatakan bahwa ada bebarapa unsur logam yang termasuk elemen mikro merupakan kelompok logam berat yang tidak mempunyai fungsi biologik sama sekali. Logam tersebut sangat berbahaya dan dapat menyebabkan keracunan (toksisitas) pada makhluk 
hidup (hewan dan manusia) yaitu timbal $(\mathrm{Pb})$, merkuri $(\mathrm{Hg})$, arsen (As), dan $\operatorname{kadmium}(\mathrm{Cd})$.

Keberadaan logam berat dalam bahan pangan dapat memenuhi pada proses pengolahan, terutama pada saat ketika dilakukan penggilingan kedelai, alat penggilingan yang digunakan telah berkarat atau perebusan dalam wadah yang terbuat dari logam serta dengan kondisi produk asam sehingga memungkinkan terjadinya kontaminasi silang dari alat ke dalam bahan pangan (Arsyi Nur Fithri, 2011).

Penelitian yang dilakukan di Laboratorium Badan Penelitian dan Pengembangan Industri BBIA (Balai Besar Industri Agro) Bogor bertujuan untuk mengetahui logam berat (kadmium, timbal, timah, dan merkuri) pada tempe dipengrajin tempe $\mathrm{X}$ dan $\mathrm{Y}$ Kota Bengkulu. Metode yang digunakan dalam penelitian ini adalah metode AAS (Atomic Absorption Spectrophotomer).

Pemeriksaan yang dilaksanakan dilakukan sebanyak 2 kali (duplo), untuk memastikan apakah sampel mengandung cemaran logam berat atau tidak. Berdasarkan hasil pemeriksaan identifikasi cemaran logam berat pada sampel tempe yang higiene sanitasi dan tidak higiene sanitasi, terdapat kandungan logam berat setiap sampel, akan tetapi kandungannya masih dalam kategori batas aman kandungan logam berat dari syarat mutu tempe berdasarkan SNI yang berarti setiap sampel masih aman untuk dikonsumsi oleh masyarakat.

Tempe $\mathrm{X}$ yang dipilih yaitu merupakan dari pengrajin tempe yang telah menerapkan prinsip higiene dan sanitasi, baik dari peralatan, tempat produksi, dan proses produksi. Tempe Y yang dipilih yaitu dari pengrajin tempe yang tidak menerapkan prinsip higiene dan sanitasi, ini terlihat dari peralatan yang digunakan (drum bekas dan alat penggilingan yang kotor) dan tempat produksi yang tidak terjaga kebersihannya. Pemilihan tempat pengrajin tempe ini menggunakan lembar ceklist selama observasi berlangsung.

Pada penelitian Pragita, Rahayuningsih dan Muslich (2015) penggunaan drum (besi) dalam proses pembuatan tempe, terlebih pada saat perebusan berpengaruh terhadap kandungan cemaran logam terutama $(\mathrm{Cd})$. Cadmium sering digunakan dalam campuran zat yang terkadang digunakan untuk melapisi drum agar tidak mudah berkarat dan memperindah tampilan drum (Lala, 2011), namun perebusan kedelai dengan suhu tinggi dapat mempercepat 
laju korosi besi sehingga partikel metode pengukusan, perebusan dan cadmium dalam cat terkelupas dan masuk penumisan dapat menurunkan kadar kedalam proses pengolahan kedelai logam berat $\mathrm{Pb}$ dan $\mathrm{Cd}$ pada daun dan menjadi tempe. buah kacang panjang. Dalam proses Syarat mutu tempe kedelai perebusan kandungan logam berat menurut BSN 2015 cemaran logam seperti maupun zat gizi juga banyak yang hilang kadmium (Cd) maks $0.2 \mathrm{mg} / \mathrm{kg}$, timbal $(\mathrm{Pb})$ maks $0.25 \mathrm{mg} / \mathrm{kg}$, timah $(\mathrm{Sn})$ maks $40 \mathrm{mg} / \mathrm{kg}$, dan merkuri (Hg) $0.03 \mathrm{mg} / \mathrm{kg}$.

Hasil kandungan logam berat pada sampel tempe $\mathrm{X}$ dan $\mathrm{Y}$ menunjukan bahwa kandungan logam berat yang terdapat bernilai sama yakni di bawah nilai yang telah dipersyaratkan oleh BSN 2015, nilai logam berat yang terkandung yaitu kadmium < $0.004 \mathrm{mg} / \mathrm{kg}$, timbal < $0.031 \mathrm{mg} / \mathrm{kg}$, timah $<0.8 \mathrm{mg} / \mathrm{kg}$, dan merkuri $<0.005 \mathrm{mg} / \mathrm{kg}$. Sampel tempe yang digunakan saat pengujian sebanyak 150 gram untuk masing-masing sampel dengan 4 uji yang dilakukan. Hasil kandungan logam berat yang terdapat pada tempe $\mathrm{X}$ dan $\mathrm{Y}$ yaitu dibawah batas maksimum ini dikarenakan pembuatan tempe dilakukan melalui bebrapa proses salah satunya proses perebusan. Proses perebusan ini berpengaruh terhadap penurunan kadar logam berat maupun kadar zat gizi pada pangan. Penelitian Hening Widowati, Widya Sartika Sulistiani, dan Agus Sutanto (2017) diketahui bahwa pengolahan dengan karena terlarut dalam air rebusan.

Kadmium adalah salah satu logam yang digunakan untuk melapisi drum supaya tidak terjadi korosi. Kadmium ini apabila dilakukan pemanasan dengan suhu tinggi menyebabkan lapisan kadmium terkelupas sehingga terbawa dan masuk kedalam tempe yang direbus menggunakan bahan yang mengandung kadmium. Perebusan yang berkali-kali dan dengan suhu yang tinggi menyebabkan lapisan kadmium pada drum yang digunakan semakin lama semakin menipis. Drum yang digunakan dalam proses perebusan ini yaitu drum yang telah digunakan hampir satu tahun dan sudah berkarat. Sampel yang diambil dalam penelitian ini merupakan sampel tempe dalam perebusan yang kesekian kalinya dalam penggunaan drum, sehingga memungkinkan lapisan kadmium tadi menipis jadi kadmium yang terkandung dalam sampel tempe ini jumlah kadmiumnya sudah minimal.

Berdasarkan hasil tersebut berarti tidak diperlukan sikap kehati-hatian dalam 
mengonsumsi tempe dari segi cemaran logam berat pada tempe, ini dikarenakan hasil penelitian menunjukan nilai dibawah batas maksimum persyaratan menurut BSN 2015 yang berarti tempe dari pengrajin tempe $\mathrm{X}$ dan $\mathrm{Y}$ aman untuk dikonsumsi, tempe $\mathrm{X}$ yaitu dari pengrajin tempe yang telah menerapkan prinsip higiene dan sanitasi sedangkan tempe $\mathrm{Y}$ yaitu dari pengrajin tempe yang belum menerapkan prinsip higiene dan sanitasi. Higiene dan sanitasi ini sangat penting diperhatikan agar makanan terjamin keamanannya dan aman untuk dikonsumsi.

\section{KESIMPULAN}

Kandungan logam berat timbal $(\mathrm{Pb})$, Cadmium $(\mathrm{Cd})$, Timah (Sn), dan

\section{DAFTAR RUJUKAN}

Agustina, Titin.(2010). Kontaminasi Logam Berat Pada Makanan dan Dampaknya Pada Kesehatan. Teknubuga, 2(2), 53-65.

Astawan,M., Wresdiyati, T., Sirait,J. (2015).

Pengaruh Konsumsi Tempa Kedelai Grobogan Terhadap Profil Serum,Hematologi dan Antioksidan Tikus. Jurnal Teknol dan Industri Pangan, 26(2), 155 -

162.HTTPS://DOI.ORG/10.6066/JTIP.201 5.26.2.155.

Astuti, S. (2008). Isoflavon Kedelai dan Potensinya Sebagai Penangkap Radikal Bebas. Teknologi Industri dan Hasil
Merkuti (Hg) di tempe padapengrajin dalambatas aman dari syarat mutu tempe menurut Badan Standarisasi Nasional (BSN) 2015.

Saran penelitian lanjutan dapat mengembangkan penelitian ini dengan mengindentifikasi kandungan yang dapat di dalam tempedari syarat mutu tempe yang lain diantaranya yaitu cemaran arsen(As), kadar air,kadar lemak,kadar protein, dan kadar serat kasar dan mengenai pemberian edukasi hygiene dan sanitasi kepada pengrajin mengenai dampak dan pengaruh kandungan logam jika terdapat pada tempe sehingga pengrajin dapat menerapkan prinsip higiene dan sanitasi dalam pembuatan tempe

Pertanian Universitas Lampung, 13(2),126136.

Badan Standarisasi Nasional. (2009). Batas Maksimum Cemaran Logam Berat Dalam Pangan. 7387, 1-29.

Badan Standarisasi Nasional. (2015). Tempe Kedelai. (3144), 1-26.

Bintari, S.H \& Maskar, D.H. (2012). Aplication of Food Hygienic Practices (GHP) At The Tempe Production in Kuripan Kidul Pekalongan. Prosiding Seminar Nasional Integrasi Kebijakan dan Penguatan Industri Nasional Menuju Percepatan dan perluasan Ekonomi Indonesia. Jurusan Ekonomi Pembangunan Fakultas Ekonomi Universitas Negeri Semarang. Pp : 368-379 
016 Jurnal Media Kesehatan, Volume 11 Nomor 2, Desember 2018, hlm. 009-016

DinasPangandanPertanian Kota Bengkulu 2017.LaporanPelaksanaanKegiatanAnalisis PenyusunanPolaKonsumsidanSuplaibPanga n Kota Bengkulu. Bengkulu

Fithri, $\quad$ A.N.,Oginawati,K., Muhayatun.(2011). Pengendalian

Kontaminasi Logam Berat di Industri Tahu Dengan Konsep Hazard Analysis Critical Control Point (HACCP). Jurnal Teknik Lingkungan, 17 (1),1-11.

Jubaidah,S., Nurhasanawati,H., Wijaya, H.(2016).Penetapan Kadar Protein Tempe Jagung (Zea masy L). Dengan kombinasi kedelai (Glicine max (L) Merril) Secara Spektrofotometri Sinar Tampak.Jurnal Ilmiah Manuntung,2(1),111-119.

Lala, F.(2011). Makalah Toksikologi kadmium. Politekkes Yogyakarta.

Marlinah, A., Hidayat, T., Husna,N. (2012). Pengaruh Varietas dan Jarak Tanam Terhadap Perumbuhan Kedelai (Glycine Max (L) Merrill).Jurnal Agrista,16(1), 2228.
Mutiara A. (2010). Analisis Pengaruh bahan bakar dan tenaga kerja terhadap produksi tempe dikota Semarang (Skripsi). Semarang : JurusanEkonomi UNDIP

Notoatmodjo, S. (2012). Metodologi Penelitian Kesahatan. Jakarta : PT Rineka Cipta.243 hlm

Pragita, T.E., Rahayuningsih,M., Muslich. (2015). Evaluasi Penyimpanan dan Perbaikan Mutu Tempe Sesuai SNI 3144 : 2015 Di UMKM. Jurnal Standarisasi. 19(2), 113-126.

Rauf, R.(2013). Sanitasi Pangan \& HACCP. Yogyakarta : Graha Ilmu.

Suwarno B. (2004). Membuat Tempe dan Oncom.Jakarta :Penebar Swadaya.

Widowati, H., Sulistianti. W.S., Susanto, Agus.(2017). Pengaruh Proses Pengolahan Terhadap Kadar Logam Berat dan Kadar Gizi Pada Kacang Panjang. Jurnal Pendidikan Biologi Universitas Muhammadiyah metro, 8(2),171-175 